\title{
Incidence of Root-Knot Nematode (Meloidogyne graminicola) and Resulting Crop Losses in Paddy Rice in Northern India
}

\author{
Mujeebur Rahman Khan ${ }^{\dagger}$ and Faheem Ahamad \\ Department of Plant Protection, Faculty of Agricultural Sciences, Aligarh Muslim University, Aligarh, Uttar Pradesh 202002, \\ India
}

\begin{abstract}
Surveys of major rice growing districts in the state of Uttar Pradesh in Northern India were conducted for 3 consecutive years during 2013 to 2015 under a government-funded major research project to determine the frequency of occurrence and disease incidence of the rice root-knot nematode, Meloidogyne graminicola, in rice paddy fields. More than 800 paddy fields from 88 Tehsils (divisions within a district) in 18 major rice growing districts in Uttar Pradesh were surveyed, where $M$. graminicola was associated with root-knot disease in rice paddy fields based on morphological and molecular characterization of juveniles and adults. The highest frequency of disease in rice fields was observed in Aligarh (44.6\%), followed by Muzaffarnagar, Shahjahanpur, and

Gall index and egg mass index values (on a 0 to 10 scale) were highest in Aligarh (3.5 and 2.1, respectively), followed by Muzaffarnagar (2.6 and 2.0) and Mainpuri (2.3 and 1.8). The average soil population of $M$. graminicola was highest in Aligarh $(3,851 \pm 297$ second-stage juveniles [J2]/kg of soil), followed by Muzaffarnagar $(2,855 \pm 602 \mathrm{~J} 2 / \mathrm{kg}$ of soil), whereas the lowest population was recorded in Barabanki $(695 \pm 400 \mathrm{~J} 2 / \mathrm{kg}$ of soil) at the time of harvesting. Relative yield losses were also determined, and the highest yield loss attributed to $M$. graminicola infestation was recorded in Aligarh (47\%). The yield loss was linearly correlated with the soil population density of $M$. graminicola and disease incidence.
\end{abstract} Kheri Lakhimpur (29.3, 28.0, and 27.4\%, respectively). Maximum disease incidence was also recorded in Aligarh (44.6\%), followed by Sultanpur, Mainpuri, and Muzaffarnagar (5.7, 5.2, and 4.5, respectively).

Keywords: paddy rice, survey, soil population, frequency of occurrence, yield loss

Rice is one of the most important food crops in the world and forms the staple food for more than half of the global population (McCouch et al. 2016). More than $90 \%$ of the world's rice is grown and consumed in Asia. In India, rice is extensively grown and occupies about $23.3 \%$ of the gross cropped area of the country, covering about 43 million hectares of land (Food and Agriculture Organization of the United Nations 2018). Rice contributes $43 \%$ of the total food grain production and $46 \%$ of the total cereal production in India. In 2016, India produced 15.88 million tons of rice, with an average productivity of $3,695 \mathrm{~kg} / \mathrm{ha}$, which is $25.5 \%$ lower than the global average rice productivity of $4,637 \mathrm{~kg} / \mathrm{ha}$ (Food and Agriculture Organization of the United Nations 2018). Various biotic and abiotic factors contribute to the lower productivity of rice in India. Among the biotic factors, nematode infestation is considered an important factor responsible for up to $72 \%$ of yield loss (Khan et al. 2014; Prasad 2011). Economically important plant nematodes in rice are Aphelenchoides besseyi, Ditylenchus angustus, Hirshmanniella oryzae, Meloidogyne graminicola, Heterodera indicus, Hoplolaimus spp., and Pratylenchus penetrans (Haque et al. 2018; Prasad et al. 2010).

Among plant nematodes, the root-knot nematode, M. graminicola, has become an emerging problem in paddy cultivation (Haque et al. 2018; Jones et al. 2013). This nematode is highly damaging to upland, lowland, and deep water rice and causes serious economic

${ }^{\dagger}$ Corresponding author: M. R. Khan; mrkhan777in@yahoo.co.in or mrkhan.amu@gmail.com

Funding: This research was carried out with financial support from the University Grant Commission Ministry of Human Resource Development, Government of India through a major research project (F. no. F. 41-1197/2012 SR to M. R. Khan).

The author(s) declare no conflict of interest.

Accepted for publication 12 July 2019.

(C) 2020 The American Phytopathological Society losses to rice grown in the nursery as well as in the field (Haque et al. 2018). The nematode is widely distributed in Southeast and South Asia (Bridge et al. 1990). The rice root-knot nematode has been recorded in some states of India, such as Jammu and Kashmir (Singh et al. 2007), Kerala (Sheela et al. 2005), Karnataka (Prasad et al. 2010), Haryana, Himachal Pradesh, Panjab (Dabur and Jain 2005; Jain et al. 2012), and Uttar Pradesh (Hassan et al. 2004; Khan et al. 2010), but its distribution and effects on yield have not yet been determined.

Infection of rice with $M$. graminicola results in growth reduction, reduced tillering, chlorosis of young plants, and production of unfilled spikelets at maturity (Babatola 1984). On roots, the nematode incites the formation of hook, spiral, or horseshoe-shaped terminal galls (Hunt and Handoo 2009). Transformation of roots into galls leads to impairment of water and mineral uptake. As a result, seedlings in the nursery or plants in the field show yellowish leaves, sparse tillering, and stunted growth (Khan and Anwer 2011). M. graminicola infestation in paddy fields may reduce yield by 15 to $30 \%$ (Khan et al. 2014; Prasad et al. 1986; Prot et al. 1994). Plowright and Bridge (1990) reported that $M$. graminicola infestation may suppress rice yield by 20 to $80 \%$ depending on the population density of the nematode. A preplant population of 1,500 juveniles of M. graminicola $/ \mathrm{kg}$ of soil may reduce the rice yield by 27 to $35 \%$ (Haque et al. 2018; Khan et al. 2014).

Because of extensive and continuous paddy rice cultivation especially under irrigation, the rice root-knot nematode has emerged as a serious nematode pest in Northern India, especially in the state of Uttar Pradesh (Haque et al. 2018). Despite the widespread occurrence of $M$. graminicola, adequate information on its distribution and the extent of crop damage in India is not available. As a result, management strategies against this nematode have not been implemented properly. Hence, systematic and extensive surveys of all tehsils at the block level (subdivisions within a tehsil) in 18 major rice growing districts spread over a total area of $71,901 \mathrm{~km}^{2}$ in Uttar Pradesh were conducted. The surveys were undertaken for 3 years (2013 to 2015) from July to October, and the incidence and population densities of M. graminicola were determined. Relative yield loss (RYL) in paddy rice as a result of this nematode was also assessed. 


\section{Materials and Methods}

Sample collection. Paddy fields in 18 major rice growing districts, including Aligarh, Allahabad, Azamgarh, Bahraich, Ballia, Barabanki, Deoria, Fatehpur, Ghaziabad, Hardoi, Kheri (Lakhimpur), Mainpuri, Muzaffarnagar, Pilibhit, Rampur, Saharanpur, Shahjahanpur, and Sultanpur, were surveyed. Ten paddy fields were surveyed in each block of various tehsils in each of the 18 districts. Ten soil samples each of soil and plants were collected from one field in a stratified random manner. The surveys were conducted at different stages of the crop, including the nursery stage ( 2 to 3 weeks after transplanting), the maturing stage (grain filling), and at harvest. The root and soil samples collected from one field (10 fields per block) were used to determine the soil population of M. graminicola, frequency of disease occurrence, and disease incidence.

Rhizosphere soil from five rice plants was collected in poly bags and brought to the laboratory ( $200 \mathrm{~g}$ per plant, $1,000 \mathrm{~g}$ per field). The composite soil sample $(1 \mathrm{~kg})$ was mixed in 8 liters of water and processed using Cobb's sieving and decanting method (using 10-, 35-, and 500mesh sieves with $2,000-, 500-$, and $26-\mu \mathrm{m}$ pores, respectively). The suspension caught on the 500-mesh sieve was incubated on a Baermann funnel for $12 \mathrm{~h}$ to isolate and count the $M$. graminicola second-stage juveniles (J2s) present in $1 \mathrm{~kg}$ of soil (Southey 1986). A precaution of continuously shaking the sieve set and decanting a smaller amount of suspension was taken to prevent clogging of the 500-mesh sieve pores. For counting, five 1-ml subsamples were taken from each sample and counted. The average of the five counts was used for further analysis.

Disease occurrence and root-knot incidence. The frequency of occurrence of root-knot of rice in each block of a tehsil of a district and the disease incidence in a field were calculated using the following formulas:

$$
\begin{aligned}
& \text { Frequency of occurrence }(\%) \\
& \begin{array}{c}
\text { Fields showing root } \\
=\frac{- \text { knot symptoms on rice plants }}{\text { Total rice fields inspected }} \times 100
\end{array}
\end{aligned}
$$

Disease incidence $(\%)$

Number of plants infected with root

$$
=\frac{- \text { knot nematodes in a field }}{\text { Total number of plants examined }} \times 100
$$

Root-knot symptoms. Above-ground symptoms such as chlorotic leaves, unthrifty foliage, and stunted plants were recorded during the surveying of the paddy fields. Thereafter, the plants were carefully uprooted to observe root galls, the characteristic symptom of nematode attack. Values for the gall index and the egg mass index per root system were determined in the laboratory. For frequency of occurrence, a field was considered infected when plants growing in the field exhibited characteristic galls on roots. Similarly, for the field disease incidence, a plant was considered infected when it showed root galls.

Root-knot and egg mass indices. The root samples were stained in acid fuchsin and lactophenol to observe galls and egg masses (Byrd et al. 1983). M. graminicola gall and egg mass index values were determined according to the standard evaluation scale for the rice rootknot index (Bridge et al. 2005) as follows: 0, no gall or egg mass on the root system; $1,10 \%$ of roots with galls or egg mass; $2,20 \%$ of roots with galls or egg mass; $3,30 \%$ of roots with galls or egg mass; $4,40 \%$ of roots with galls or egg mass; $5,50 \%$ of roots with galls or egg mass; $6,60 \%$ of roots with galls or egg mass; $7,70 \%$ of roots with galls or egg mass; $8,80 \%$ of roots with galls or egg mass; $9,90 \%$ of roots with galls or egg mass; and 10, all roots with galls or egg mass.

Yield loss assessment. The yield loss assessment was conducted with the difference between the attainable and the actual yield (Zadoks 1985). The functional relationships between production situation, attainable yield, and actual yield were calculated using the following formula:

$$
\mathrm{RYL}=100(\mathrm{Ya}-\mathrm{Y}) / \mathrm{Ya}
$$

where Ya is the attainable yield as per specification of the cultivar and $\mathrm{Y}$ is the yield actually obtained (Zadoks 1985).
Identification of M. graminicola. The identity of M. graminicola was determined on the basis of morphological characteristics of $\mathrm{J} 2 \mathrm{~s}$, perineal patterns of mature females, and molecular characteristics.

Morphology of juveniles. Morphological characteristics of $\mathrm{J} 2 \mathrm{~s}$ extracted from soil samples as well as those obtained from egg masses excised from the infected rice roots were studied (Hussey and Barker 1973). The juveniles were killed and fixed by adding an equal volume of boiling and double-strength triethanolamine formalin fixative (TAF) to the nematode suspension in water (Courtney et al. 1955). Temporary mounts of $\mathrm{J} 2 \mathrm{~s}$ were prepared in TAF on glass microscope slides. Morphometric measurements were recorded using an ocular micrometer at $400 \times$ magnification.

Perineal pattern. Adult females were isolated from galled root. The females were placed in $45 \%$ lactic acid on a glass slide, and the perineal pattern was cut from the posterior end of the female. The section was cleaned and trimmed. Thereafter, the perineal pattern was transferred to another slide, with the outer surface side up, and mounted in glycerin with a glass coverslip for microscopic observation.

Molecular identification. Genomic DNA from the juveniles was extracted by maceration using proteinase $\mathrm{K}$, as described previously (Subbotin et al. 2001). The genomic DNA of the nematode was used for the amplification of region between $18 \mathrm{~S}$ and $26 \mathrm{~S}$ using sense $18 \mathrm{~S}$ (5'-TTGATTACGTCCCTGCCCTTT-3') and antisense 26S (5'TTTCACTCGCCGTTACTAAGG-3') primers (Vrain et al. 1992) in a DNA Engine Tetrad 2 Peltier Thermal Cycler (Bio-Rad). The reaction mixture contained $1 \mathrm{U}$ of Dr. Max DNA polymerase (Doctor Protein Inc.), $200 \mathrm{nM}$ of dNTP mixture, $1.5 \mathrm{mM}$ of $\mathrm{MgCl}_{2}$, and $100 \mathrm{ng}$ of template DNA. The amplification conditions were as follows: initial denaturation at $94^{\circ} \mathrm{C}$ for $5 \mathrm{~min}$, followed by 30 cycles of denaturation at $94^{\circ} \mathrm{C}$ for $1 \mathrm{~min}$, annealing at $55^{\circ} \mathrm{C}$ for $1 \mathrm{~min}$, extension at $72^{\circ} \mathrm{C}$ for $1 \mathrm{~min}$, and final extension at $72^{\circ} \mathrm{C}$ for $10 \mathrm{~min}$. An aliquot of the amplified product was electrophoresed on $1 \%$ agarose. The remaining product was purified by column purification using the QIAquick PCR Purification Kit per the manufacturer's instructions. The purified PCR product was subjected to Sanger sequencing with the BigDye Terminator version 3.1 sequencing kit and a 3730xl automated sequencer (Applied Biosystems). Both strands of the amplified DNA were sequenced at the Macrogen sequencing facility in Seoul, Korea.

Statistical analysis. Surveys were conducted during 3 years (2013 to 2015) to collect the root and soil samples from all of the blocks of a district. In each block, 10 paddy fields were randomly selected for taking observations, and five soil and root samples were randomly collected from each field. The data obtained from five samples in a field were pooled to calculate the mean value. Hence, there were five replicates in a block, which were analyzed for the SD, SEM, and coefficient of variance $(\mathrm{CV} \%)$ within a district using the $\mathrm{R}$ software Agricolae package (De Mendiburu 2019). Frequency of root-knot disease occurrence, disease severity, gall index, egg mass index, and $M$. graminicola soil population were determined from samples collected from nurseries and fields. Regression analysis of soil population versus yield, root-knot index versus yield, and soil population versus root-knot index was also performed using Microsoft Excel 2016.

For nematode body measurements, the data on 10 observations were pooled to calculate the mean value of the selected morphometric characteristics of $M$. graminicola J2s isolated from the 18 districts and analyzed for the SEM, SD, CV\%, and least significant difference $(P \leq 0.05)$. Duncan's multiple range test was used to distinguish the significant variation among the juveniles.

\section{Results}

Identity of rice root-knot nematode, $M$. graminicola. The adult females were pear shaped (globular to oval), and the perineal patterns corresponded with those described for $M$. graminicola. The perineal pattern was dorsoventrally ovoid. The dorsal arch was high and squarish with four semicircular whorls on each corner of the vulvar slit (Fig. 1). The tail arch was generally high and squarish, and the 
tail terminal area was flat with shallow transverse striae. Lateral fields were not clearly visible. The striae were generally smooth and continuous around the entire pattern.

The $\mathrm{J} 2 \mathrm{~s}$ were short $(0.3$ to $0.5 \mathrm{~mm})$ with a weak cephalic framework. The esophageal gland lobe overlapped the intestine ventrally. The tail tip tapered to a long, fine point with a long hyaline region. Morphometric measurements of J2s varied among the isolates collected from 18 districts of Uttar Pradesh (Table 1). Among all isolates, the juvenile body length ranged from 408 to $480 \mu \mathrm{m}$, and this variation was significantly different $(P \leq 0.05)$. However, variations in stylet length and $a$ value (body length/maximum body width), $b$ value (length/esophagus length), and $c$ value (length/tail to terminus) were not significant (Table 1).

All isolates used in this study produced the same size amplicon with the primers. The 5.8s rDNA-internal transcribed spacer region gene sequences were subjected to a similarity search using BLAST to identify and download the similar sequences from the NCBI database. The gene sequences obtained in this study were submitted to the GenBank Nucleotide database under accession numbers MH265215 and MH265945 (M. graminicola AMUMG-1 and AMUMG-2). Species were identified by a simple comparison with available sequences of known $M$. graminicola. Phylogenetic positions using the unweighted pair group method with the arithmetic mean method in MEGA-6 software in relation to other related organisms are shown in Figure 2. AMUMG-1 grouped with the isolates from Delhi, whereas AMUMG-2 grouped with the isolate from Tuku (Fig. 2).

Gall shape and position of egg masses. Galls observed on the rice roots collected during the surveys resembled typical $M$. graminicola symptoms. The galls were invariably terminal on the lateral roots and sharply curved, in almost a ring-like spiral or a horseshoe shape. Unlike other Meloidogyne species, the egg masses incited by $M$. graminicola were not formed on the root surface (gall). The egg masses were embedded within the galled tissue and
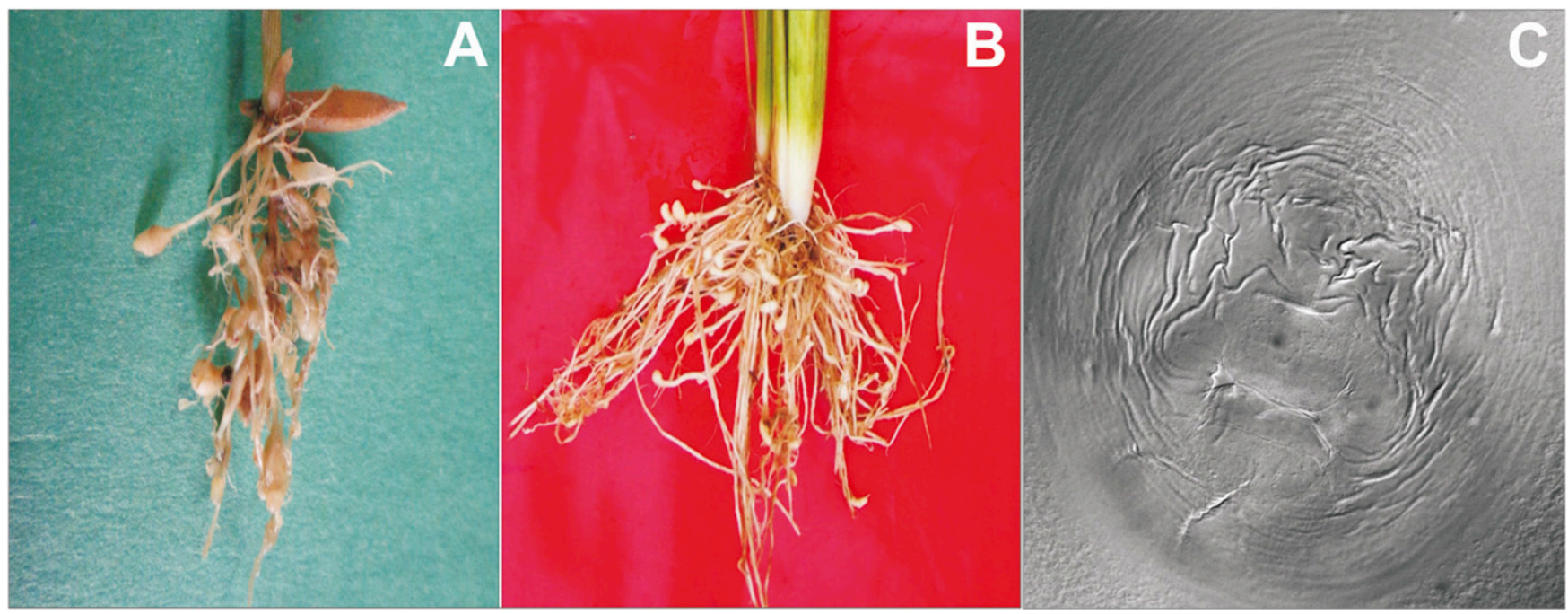

Fig. 1. Root system of paddy rice infested with Meloidogyne graminicola. A, Seedling. B, Mature plant. C, Perineal pattern.

Table 1. Morphometrics in selected characters of second-stage juveniles of Meloidogyne graminicola of the 18 districts of Uttar Pradesh ${ }^{\mathrm{z}}$

\begin{tabular}{|c|c|c|c|c|c|}
\hline District & Body length & Stylet length & $a$ value & $b$ value & $c$ value \\
\hline garh & $\mathrm{ab}$ & $\mathrm{a}$ & $\mathrm{b}$ & \pm 0 & + \\
\hline & & & & & \\
\hline Azamgarh & $25-452)=$ & $1.1(9.5-1$ & $.0(28.2-32.5)=$ & $3.3(2.7-2$ & a \\
\hline Bahraich & $9.4(455-470) \pm 5.6 \mathrm{bc}$ & $11.8(11.5$ & $.7(26.8-34.4) \pm 3.6 \mathrm{ab}$ & $2.9(2.4-3$. & $.3 \mathrm{a}$ \\
\hline Ballia & 440) $\pm 3.8 \mathrm{klm}$ & 2) $\pm 0.9 \mathrm{ab}$ & 7.2) $\pm 4.7 \mathrm{ab}$ & $2.7(2.2-3$. & $6 \mathrm{a}$ \\
\hline Barabanki & $462.8(455-478) \pm 8.5 b$ & $11.3(9.8-12.5) \pm 1.0 \mathrm{ab}$ & $29.1(26.6-33.4) \pm 2.9 \mathrm{ab}$ & $3.3(2.8-4.2) \pm 0.47 b c$ & $0.4 \mathrm{a}$ \\
\hline Deoria & $441.2(433-450) \pm 6.8 \mathrm{hij}$ & 5) $\pm 1.4 \mathrm{a}$ & $1 \mathrm{ab}$ & $3.0(2.4-3$ & $0.5 \mathrm{a}$ \\
\hline Fatehpur & $439.0(418-452) \pm 12.0 \mathrm{ijk}$ & 2.9) $\pm 1.3 \mathrm{a}$ & $30.2(27.1-35.8)=$ & $2.9(2.1-3.7) \pm 0.65$ ef & 6.4( \\
\hline Ghaz & $450.8(441-458) \pm 6.0 \mathrm{fg}$ & $112(99-$ & $27.9(27.4-31.2)$ & $3.3(2.4-4$. & $0.3 \mathrm{a}$ \\
\hline Hardoi & $20-433) \pm 4.4$ no & $.1 \mathrm{ab}$ & $a b$ & 3.5 & $0.3 \mathrm{a}$ \\
\hline Kheri (I & $437.8(428-455) \pm 10.2 \mathrm{jkl}$ & $11.8(10.2-12.6) \pm 0.9 \mathrm{a}$ & $29.8(27.3-31.8) \pm 1.7 \mathrm{ab}$ & $3.0(2.2-3.9) \pm 0.65 \mathrm{def}$ & $6.3(5.6-6.8) \pm 0.5 \mathrm{a}$ \\
\hline Mainpuri & $444.4(430-452) \pm 7.9 \mathrm{hi}$ & $11.3(9.5-12.5) \pm 1.2 \mathrm{ab}$ & $29.2(27.7-32.8) \pm 2.2 \mathrm{ab}$ & $3.1(2.3-4.1) \pm 0.76 \mathrm{def}$ & $0.4 \mathrm{a}$ \\
\hline Muzaffarnagar & $476.0(4$ & & $.4 \mathrm{ab}$ & $3.3(2.8-4$ & $0.3 \mathrm{a}$ \\
\hline Pilibhit & 4 & & $1 \mathrm{a}$ & 3.1 & $.4 \mathrm{a}$ \\
\hline ur & 4 & $2 \mathrm{a}$ & $\mathrm{ab}$ & 3.1 & 6.3 \\
\hline Sal & 47 & 11 & 30 & 2.8 & 6.4 \\
\hline Shahj & 432.6( & $\pm 1.0 \mathrm{a}$ & $31.1(26.8-3$ & $3.0(2.4-$ & 6.3( \\
\hline Sultanpur & $425.2(408-441) \pm 10.5 \mathrm{o}$ & $11.6(9.5-14.1) \pm 1.6 \mathrm{a}$ & $29.8(27.6-33.0) \pm 2.2 \mathrm{ab}$ & $2.8(2.1-4.3) \pm 0.79 \mathrm{f}$ & $6.4(6.1-7.0) \pm 0.3 \mathrm{a}$ \\
\hline SEM & 2.094 & & 1.229 & 0.150 & 0.102 \\
\hline $\mathrm{CV} \%$ & 1.042 & 5.968 & 9.233 & 10.812 & 3.567 \\
\hline $\operatorname{LSD}(P \leq 0.05)$ & 5.90 & 0.85 & 3.46 & 0.42 & 0.29 \\
\hline
\end{tabular}

${ }^{\mathrm{z}}$ Each value is the mean (range) \pm SD of 10 observations. Values within a column followed by the same letter are not significantly different at $P \leq 0.05$ according to Duncan's multiple range test. $a$ value = body length/maximum body width, $b$ value $=$ length/esophagus length, $c$ value $=$ length $/$ tail to terminus, $\mathrm{CV} \%=$ coefficient of variance, and LSD = least significant difference. 
generally became visible upon tearing the galls (Fig. 1; Yik and Birchfield 1979).

Frequency of root-knot disease occurrence. Nursery. The frequency of rice root-knot disease occurrence caused by M. graminicola in the nursery among the 18 districts of Uttar Pradesh varied from 4.5 to $23.2 \%$ (Table 2). District-wise, the higher frequencies of occurrence were recorded in Aligarh (23.2\%) and Shahjahanpur (16.0\%), and the lowest was recorded in Allahabad (4.5\%; Table 2).

Field. The frequency of root-knot nematode occurrence in the rice fields varied from 7.5 to $44.6 \%$ (Table 3 ). The highest frequency was recorded in Aligarh (44.6\%), with a variation of 17 (Ghabana Tehsil) to $59 \%$ (Khair Tehsil; Fig. 3).

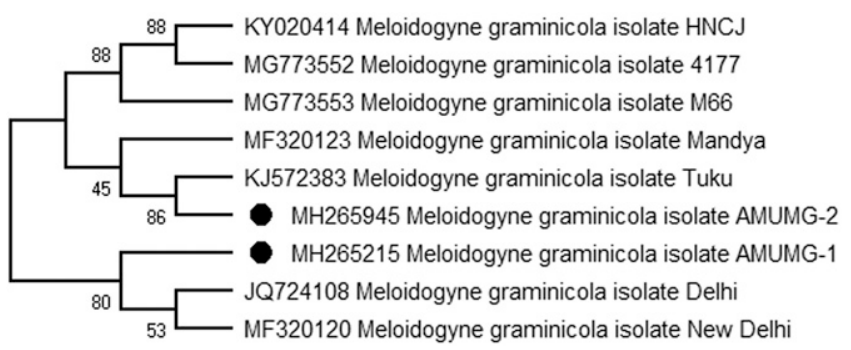

Fig. 2. A molecular phylogenetic analysis of Meloidogyne graminicola based on the internal transcribed spacer sequences by the maximum likelihood method using a general time-reversible model.
Disease incidence in the nursery and field. The overall rice root-knot disease incidence surveyed in 18 districts of Uttar Pradesh varied from 12.6 to $36.2 \%$ (Table 2). The highest nursery disease incidence was in Muzaffarnagar (36.2\%) and the lowest was in Azamgarh $(12.6 \%)$. In the rice fields, the highest disease incidence was in Sultanpur (51.0\%) and the lowest was in Azamgarh $(20.3 \%$; Table 3).

Gall and egg mass indices. Nursery. In the nursery beds, the gall index of M. graminicola varied from 1.7 to 4.9 (on a 0 to 10 scale), being highest in Aligarh (4.9) and lowest in Barabanki (1.7; Table 2). The egg mass index of $M$. graminicola in the nursery varied from 0.4 to 1.4 (on a 0 to 10 scale; Table 2).

Field. In the paddy fields, the gall index varied from 1.7 to 7.0 (on a 0 to 10 scale; Table 3 ). The highest galling in rice roots was recorded in Aligarh (Table 3). The egg mass index on rice plants collected from the fields varied from 1.5 to 4.4 (on a 0 to 10 scale; Table 3). The highest egg mass index was recorded in Aligarh and the lowest was recorded in Fatehpur and Bahraich (Table 3).

M. graminicola population in soil. Nursery. $\mathrm{J} 2$ levels ranged from $610 \pm 320 \mathrm{~J} 2 / \mathrm{kg}$ of soil (Barabanki) to $3,060 \pm 237 \mathrm{~J} 2 / \mathrm{kg}$ of soil (Aligarh; Table 2). Other plant parasitic nematodes recovered included Helicotylenchus, Hoplolaimus, Tytlenchorhynchus, Rotylenchus, Rotylenchulus, Ditylenchus, Trichodorus, and Hirschmanniella species and some free-living nematodes (not identified).

Field. The soil population of M. graminicola was also recorded in the paddy fields in all 18 districts of Uttar Pradesh, with the highest population in Aligarh $(3,851 \pm 297 \mathrm{~J} 2 / \mathrm{kg}$ of soil $)$ and the lowest in Barabanki (695 $\pm 400 \mathrm{~J} 2 / \mathrm{kg}$ of soil; Table 3). In addition to

Table 2. Frequency of occurrence, root-knot index, and soil population of Meloidogyne graminicola (MG) in nursery beds of paddy in the 18 districts of Uttar Pradesh

\begin{tabular}{|c|c|c|c|c|c|}
\hline District & $\begin{array}{l}\text { Frequency of } \\
\text { occurrence (\%) }\end{array}$ & Disease severity & $\begin{array}{l}\text { Gall index } \\
(0-10 \text { scale })\end{array}$ & $\begin{array}{l}\text { Egg mass index } \\
(0-10 \text { scale })\end{array}$ & $\begin{array}{l}\text { Soil population } \\
\text { (MG J2/kg of soil) }\end{array}$ \\
\hline Aligarh & $23.2 \pm 7.7 \mathrm{a}$ & $33.4 \pm 4.8 \mathrm{abc}$ & $4.9 \pm 0.20 \mathrm{a}$ & $1.3 \pm 0.22 \mathrm{a}$ & $3,060 \pm 237 \mathrm{a}$ \\
\hline Allahabad & $7.7 \pm 4.2 \mathrm{fg}$ & $20.9 \pm 7.6 \mathrm{ef}$ & $2.0 \pm 0.92 \mathrm{hi}$ & $0.7 \pm 0.37 \mathrm{fg}$ & $677 \pm 484 \mathrm{hi}$ \\
\hline Azamgarh & $8.3 \pm 4.1 \mathrm{fg}$ & $12.6 \pm 5.0 \mathrm{~g}$ & $2.3 \pm 0.72 \mathrm{ghi}$ & $0.8 \pm 0.41 \mathrm{ef}$ & $915 \pm 468$ fghi \\
\hline Bahraich & $8.8 \pm 2.9 \mathrm{f}$ & $18.5 \pm 3.9 \mathrm{fg}$ & $1.8 \pm 0.55 \mathrm{f}$ & $0.4 \pm 0.22 \mathrm{i}$ & $616 \pm 195 \mathrm{i}^{\circ}$ \\
\hline Ballia & $11.7 \pm 2.7 \mathrm{cde}$ & $26.8 \pm 4.8 \mathrm{de}$ & $2.1 \pm 0.48 \mathrm{hi}$ & $0.7 \pm 0.31 \mathrm{fg}$ & $924 \pm 318 \mathrm{fghi}$ \\
\hline Barabanki & $9.0 \pm 2.4 \mathrm{ef}$ & $28.3 \pm 4.7 \mathrm{~cd}$ & $1.7 \pm 0.67 \mathrm{f}$ & $0.7 \pm 0.37 \mathrm{fg}$ & $610 \pm 320 \mathrm{i}$ \\
\hline Deoria & $11.6 \pm 1.7 \mathrm{cde}$ & $28.4 \pm 2.9 \mathrm{~cd}$ & $2.9 \pm 0.59 \mathrm{efg}$ & $1.2 \pm 0.18 \mathrm{~b}$ & $1,015 \pm 187 \mathrm{defg}$ \\
\hline Fatehpur & $5.8 \pm 2.9 \mathrm{gh}$ & $19.3 \pm 6.1 \mathrm{f}$ & $1.8 \pm 0.70 \mathrm{f}$ & $0.6 \pm 0.25 \mathrm{fgh}$ & $787 \pm 363 \mathrm{ghi}$ \\
\hline Ghaziabad & $9.3 \pm 1.5 \mathrm{ef}$ & $26.3 \pm 13.0 \mathrm{de}$ & $3.4 \pm 1.47 \mathrm{cde}$ & $1.1 \pm 0.45 \mathrm{bc}$ & $1,291 \pm 501 \mathrm{cde}$ \\
\hline Hardoi & $12.8 \pm 2.9 \mathrm{~cd}$ & $28.8 \pm 3.1 \mathrm{~cd}$ & $2.4 \pm 0.63 \mathrm{ghi}$ & $1.2 \pm 0.25 \mathrm{~b}$ & $985 \pm 136$ efgh \\
\hline Kheri (Lakhimpur) & $13.4 \pm 4 b c$ & $32.0 \pm 2.3 \mathrm{abcd}$ & $3.5 \pm 0.45 \mathrm{cde}$ & $1.4 \pm 0.12 \mathrm{a}$ & $1,458 \pm 197 \mathrm{c}$ \\
\hline Mainpuri & $12.7 \pm 2.6 \mathrm{~cd}$ & $33.3 \pm 4.1 \mathrm{abc}$ & $3.9 \pm 0.31 \mathrm{bc}$ & $1.2 \pm 0.39 \mathrm{~b}$ & $1,980 \pm 482 b$ \\
\hline Muzaffarnagar & $13.5 \pm 3.7 \mathrm{bc}$ & $36.2 \pm 4.6 \mathrm{a}$ & $4.3 \pm 0.21 \mathrm{ab}$ & $1.1 \pm 0.24 b c$ & $2,298 \pm 333 b$ \\
\hline Pilibhit & $14.0 \pm 3.7 \mathrm{bc}$ & $27.0 \pm 1.6 \mathrm{de}$ & $3.1 \pm 0.53 \mathrm{ef}$ & $1.0 \pm 0.25 \mathrm{~d}$ & $1,336 \pm 202 \mathrm{~cd}$ \\
\hline Rampur & $4.5 \pm 2.8 \mathrm{~h}$ & $21.3 \pm 14.9$ ef & $2.2 \pm 1.43 \mathrm{hi}$ & $0.8 \pm 0.47$ ef & $846 \pm 488 \mathrm{defg}$ \\
\hline Saharanpur & $10.2 \pm 2.5 \mathrm{def}$ & $26.4 \pm 5.2 \mathrm{de}$ & $2.7 \pm 0.77 \mathrm{fgh}$ & $1.1 \pm 0.20 b c$ & $1,361 \pm 366 \mathrm{c}$ \\
\hline Shahjahanpur & $16.0 \pm 3.1 \mathrm{~b}$ & $29.8 \pm 3.4 \mathrm{bcd}$ & $3.2 \pm 0.69 \mathrm{def}$ & $1.1 \pm 0.20 \mathrm{bc}$ & $1,191 \pm 216 \mathrm{cdef}$ \\
\hline Sultanpur & $13.0 \pm 7.8 \mathrm{~cd}$ & $36.0 \pm 3.4 \mathrm{ab}$ & $3.9 \pm 1.07 \mathrm{bcd}$ & $1.3 \pm 0.17 \mathrm{a}$ & $1,974 \pm 775 b$ \\
\hline SEM & 0.136 & 0.055 & 64.757 & 0.559 & 1.247 \\
\hline $\mathrm{CV} \%$ & 10.48 & 10.433 & 11.093 & 10.953 & 10.338 \\
\hline $\operatorname{LSD}(P \leq 0.05)$ & 1.56 & 3.48 & 0.38 & 0.15 & 179.98 \\
\hline \multicolumn{6}{|l|}{ ANOVA } \\
\hline \multicolumn{6}{|l|}{ District } \\
\hline$d f$ & 17 & 17 & 17 & 17 & 17 \\
\hline Sum of squares & $1,517.6$ & 3,479 & 73.60 & 13.658 & $35,990,917$ \\
\hline Mean squares & 89.27 & 204.66 & 4.330 & 0.8034 & $2,117,113$ \\
\hline$F$ value & 58.15 & 26.78 & 47.63 & 54.94 & 103.9 \\
\hline $\operatorname{Pr}(>F)$ & $<2 \mathrm{e}-16^{*}$ & $<2 \mathrm{e}-16^{*}$ & $<2 \mathrm{e}-16^{*}$ & $<2 \mathrm{e}-16^{*}$ & $<2 \mathrm{e}-16^{*}$ \\
\hline \multicolumn{6}{|l|}{ Residuals } \\
\hline$d f$ & 72 & 72 & 72 & 72 & 72 \\
\hline Sum of squares & 110.5 & 550 & 6.55 & 1.053 & $1,467,485$ \\
\hline Mean squares & 1.54 & 7.64 & 0.091 & 0.0146 & 20,382 \\
\hline
\end{tabular}

${ }^{\mathrm{z}}$ Each value is the mean $\pm \mathrm{SD}$ of all observations from the different blocks of a district. Values followed by different letters within the column are significantly different at $P \leq 0.05$ according to Duncan's multiple range test. * Values are significant at $P \leq 0.05$. J2 $=$ second-stage juvenile, CV\% $=$ coefficient of variance, $\mathrm{LSD}=$ least significant difference, ANOVA $=$ analysis of variance, $d f=$ degrees of freedom, and $\operatorname{Pr}=P$-value for the effect of the classification variable on the response 
M. graminicola, other nematodes, especially Hemicriconemoides, Hoplolaimus, Hemicycliophora, Tytlenchorhynchus, Rotylenchus, Rotylenchulus, Ditylenchus, Trichodorus, Pratylenchus, Helicotylenchus, and Hirschmanniella species and some free-living nematodes, were also recovered in the soil samples, and their cumulative populations were approximately 4 to $9 \%$ of the $M$. graminicola population.

Relative yield loss. The RYL attributable to root-knot disease caused by $M$. graminicola ranged from 7.0 to $46.7 \%$. Besides the nematode attack, soil nutrition and other diseases may also contribute to the yield suppression. However, in view of the economic value of rice, growers generally give recommended inputs of fertilizers and pesticides to the fields. Hence, the lower yields may be conceivably attributed to $M$. graminicola, as any visible symptom attributable to other diseases was not observed. The maximum RYL was recorded in Aligarh and the lowest in Barabanki (Table 3).

\section{Discussion}

On the basis of morphology and molecular data, the identity of a root-knot nematode species causing galling on rice plants collected from nurseries and paddy fields in 18 districts of Uttar Pradesh was confirmed as $M$. graminicola. This species was previously reported as a causal agent of root-knot of rice in scattered areas in India (Dabur et al. 2004; Khan et al. 2010; Singh et al. 2007). This study on the occurrence of $M$. graminicola on rice from 18 districts of Uttar Pradesh is the first comprehensive report of rice infestation with M. graminicola. This report was made from systematic surveys covering a large area spread over $71,901 \mathrm{~km}^{2}$ in Northern India conducted during 2013 to 2015 under a government-funded research project.
The nematode-infested nurseries showed stunted growth and discernable leaf yellowing, which are characteristic symptoms of $M$. graminicola damage at the seedling stage (Luc et al. 2005). The nematode causes a characteristic hook shape or spiral terminal galls on rice roots (Ahamad and Khan 2018; Dabur et al. 2004; Sheela et al. 2005). Galling severity varied considerably among the districts surveyed. There was a direct correlation between disease severity and $\mathrm{J} 2$ soil population densities of $M$. graminicola at harvest as revealed by regression analysis (Fig. 4). As a result, the areas/fields having a higher nematode population exhibited severe galling (higher disease severity). For example, in Aligarh, Muzaffarnagar, and Mainpuri, the soil population of $M$. graminicola at harvesting time was as high as $3,851,2,855$, and 2,650 J2/kg of soil and the RYLs were 46.7, 35.7, and $34.9 \%$, respectively. Poudyal et al. (2005) reported that an initial population of 1,000 and 10,000 M. graminicola $\mathrm{J} 2 / \mathrm{kg}$ of soil may reduce the rice yield by 31 and $97 \%$, respectively. The yield loss reported above at the given population level is much greater than our observations. In fact, Poudyal et al. (2005) measured the nematode population at the planting stage, which would have increased during the crop season. However, in our study, the population was measured at the harvesting stage and would have been considerably lower at planting time. Other experiments have shown that 4,000 M. graminicola juveniles per plant may cause up to $72 \%$ crop loss (Bridge and Page 1982), whereas $1,500 \mathrm{~J} 2 / \mathrm{kg}$ of soil reduces the yield by 27 to $32 \%$ (Haque et al. 2018). In this study, a strong negative correlation was recorded for yield versus soil population at harvest $\left(R^{2}=0.869\right)$ and for yield versus root-knot index $\left(R^{2}=0.937\right)$ and a positive correlation was recorded for soil population at harvest versus root-knot index $\left(R^{2}=0.918\right.$; Fig. 4).

Table 3. Frequency of occurrence, root-knot index, and soil population of Meloidogyne graminicola (MG) in paddy fields at maturity stage (3 months) in the 18 districts of Uttar Pradesh ${ }^{\mathrm{z}}$

\begin{tabular}{|c|c|c|c|c|c|c|c|}
\hline District & $\begin{array}{c}\text { Frequency of } \\
\text { occurrence (\%) }\end{array}$ & Disease severity & $\begin{array}{l}\text { Gall index } \\
(0-10 \text { scale })\end{array}$ & $\begin{array}{l}\text { Egg mass index } \\
(0-10 \text { scale })\end{array}$ & $\begin{array}{c}\text { Soil population } \\
\text { (MG J2/kg } \\
\text { of soil) }\end{array}$ & Yield (Q/ha) & $\begin{array}{c}\text { Relative } \\
\text { yield loss (\%) }\end{array}$ \\
\hline Aligarh & $44.6 \pm 15.0 \mathrm{a}$ & $47.9 \pm 6.8 \mathrm{ab}$ & $7.0 \pm 0.43 \mathrm{a}$ & $4.4 \pm 0.37 \mathrm{a}$ & $3,851 \pm 297 \mathrm{a}$ & $21.33 \pm 0.30 \mathrm{c}$ & $46.68 \pm 0.76 \mathrm{a}$ \\
\hline Allahabad & $15.2 \pm 6.9 \mathrm{fgh}$ & $33.4 \pm 14.2 \mathrm{efg}$ & $2.0 \pm 0.63 \mathrm{ghi}$ & $1.6 \pm 0.48 \mathrm{ij}$ & $720 \pm 605 \mathrm{hi}$ & $36.33 \pm 2.34 \mathrm{a}$ & $9.18 \pm 5.85 \mathrm{fg}$ \\
\hline Azamgarh & $15.7 \pm 7.6 \mathrm{fg}$ & $20.3 \pm 7.9 \mathrm{~h}$ & $2.4 \pm 0.44$ fghi & $1.8 \pm 0.33 \mathrm{hij}$ & $1,150 \pm 585 \mathrm{fghi}$ & $35.18 \pm 3.50 \mathrm{a}$ & $12.05 \pm 8.75$ ef \\
\hline Bahraich & $11.8 \pm 4.3 \mathrm{ghi}$ & $26.5 \pm 5.2 \mathrm{gh}$ & $1.8 \pm 0.32 \mathrm{hi}$ & $1.5 \pm 0.29 \mathrm{j}$ & $705 \pm 243 \mathrm{i}$ & $36.59 \pm 1.12 \mathrm{a}$ & $8.52 \pm 2.80 \mathrm{i}$ \\
\hline Ballia & $21.2 \pm 7.4 \mathrm{de}$ & $33.3 \pm 6.4$ efg & $2.5 \pm 0.47 \mathrm{fgh}$ & $2.1 \pm 0.41$ ghij & $1,175 \pm 398$ fghi & $36.52 \pm 2.46 \mathrm{a}$ & $8.70 \pm 6.16 \mathrm{fg}$ \\
\hline Barabanki & $17.8 \pm 2.9 \mathrm{ef}$ & $34.5 \pm 4.8$ efg & $1.7 \pm 0.42 \mathrm{i}$ & $1.6 \pm 0.37 \mathrm{j}$ & $695 \pm 400 \mathrm{i}$ & $37.19 \pm 0.67 \mathrm{a}$ & $7.03 \pm 1.67 \mathrm{~g}$ \\
\hline Deoria & $23.4 \pm 5.0 \mathrm{~cd}$ & $35.0 \pm 4.4$ ef & $3.0 \pm 0.24 \mathrm{def}$ & $2.4 \pm 0.25 \mathrm{efgh}$ & $1,122 \pm 293 \mathrm{defg}$ & $31.40 \pm 1.06 \mathrm{ab}$ & $21.50 \pm 2.66 \mathrm{c}$ \\
\hline Fatehpur & $10.3 \pm 5.2 \mathrm{hi}$ & $28.0 \pm 9.0 \mathrm{fgh}$ & $1.8 \pm 0.32 \mathrm{hi}$ & $1.5 \pm 0.26 \mathrm{j}$ & $980 \pm 233$ ghi & $36.31 \pm 2.91 \mathrm{ab}$ & $9.22 \pm 7.29 \mathrm{fg}$ \\
\hline Ghaziabad & $16.8 \pm 4.1 \mathrm{efg}$ & $33.5 \pm 17.4 \mathrm{efg}$ & $3.4 \pm 0.41 \mathrm{de}$ & $2.9 \pm 0.32 \mathrm{de}$ & $1,625 \pm 454 \mathrm{cde}$ & $31.22 \pm 4.71 \mathrm{ab}$ & $21.95 \pm 11.77 \mathrm{c}$ \\
\hline Hardoi & $25.4 \pm 3.6 \mathrm{bcd}$ & $34.6 \pm 3.8 \mathrm{efg}$ & $2.6 \pm 0.87$ efg & $2.2 \pm 0.65$ fghi & $1,220 \pm 626$ efgh & $33.95 \pm 2.27 \mathrm{a}$ & $15.13 \pm 5.68 \mathrm{de}$ \\
\hline Kheri (Lakhimpur) & $27.4 \pm 5.2 \mathrm{bc}$ & $40.0 \pm 2.0$ bcde & $3.8 \pm 0.33 \mathrm{~cd}$ & $3.0 \pm 0.24 \mathrm{cdr}$ & $2,230 \pm 170 \mathrm{c}$ & $32.70 \pm 3.20 \mathrm{ab}$ & $18.25 \pm 8.00 \mathrm{~cd}$ \\
\hline Mainpuri & $24.7 \pm 10.0 \mathrm{bcd}$ & $46.0 \pm 7.0 \mathrm{abc}$ & $4.5 \pm 0.28 \mathrm{bc}$ & $3.6 \pm 0.21 b c$ & $2,650 \pm 246 \mathrm{~b}$ & $26.01 \pm 3.43 \mathrm{bc}$ & $34.98 \pm 8.59 \mathrm{~b}$ \\
\hline Muzaffarnagar & $29.3 \pm 7.8 \mathrm{~b}$ & $45.0 \pm 6.9 \mathrm{abcd}$ & $5.2 \pm 0.34 \mathrm{~b}$ & $4.0 \pm 0.25 \mathrm{ab}$ & $2,855 \pm 602 b$ & $25.74 \pm 4.01 \mathrm{bc}$ & $35.65 \pm 10.03 b$ \\
\hline Pilibhit & $24.3 \pm 4.6 \mathrm{bcd}$ & $37.0 \pm 3.7 \mathrm{de}$ & $3.4 \pm 0.50 \mathrm{de}$ & $2.6 \pm 0.25 \mathrm{efg}$ & $1,610 \pm 749 \mathrm{~cd}$ & $32.78 \pm 1.64 \mathrm{ab}$ & $18.05 \pm 4.10 \mathrm{~cd}$ \\
\hline Rampur & $7.5 \pm 5.4 \mathrm{i}$ & $27.0 \pm 19.0 \mathrm{fgh}$ & $2.8 \pm 0.29 \mathrm{ef}$ & $2.0 \pm 0.22$ ghij & $765 \pm 417 \mathrm{ghi}$ & $35.15 \pm 2.88 \mathrm{a}$ & $12.13 \pm 7.20$ ef \\
\hline Saharanpur & $15.0 \pm 4.1 \mathrm{fg}$ & $33.8 \pm 6.9$ efg & $2.8 \pm 0.33$ ef & $2.8 \pm 0.28$ ef & $1,750 \pm 253 \mathrm{c}$ & $31.99 \pm 1.95 \mathrm{ab}$ & $20.03 \pm 4.87 \mathrm{~cd}$ \\
\hline Shahjahanpur & $28.0 \pm 2.8 b c$ & $39.0 \pm 3.7 \mathrm{cde}$ & $3.4 \pm 0.81 \mathrm{de}$ & $2.8 \pm 0.54 \mathrm{ef}$ & $1,200 \pm 730 \mathrm{cdef}$ & $32.39 \pm 1.83 \mathrm{ab}$ & $19.03 \pm 4.59 \mathrm{~cd}$ \\
\hline Sultanpur & $21.0 \pm 16.3 \mathrm{de}$ & $51.0 \pm 11.6 \mathrm{a}$ & $4.6 \pm 0.34 b c$ & $3.5 \pm 0.31 \mathrm{bcd}$ & $2,425 \pm 457 \mathrm{~b}$ & $25.72 \pm 2.79 b c$ & $35.70 \pm 6.99 \mathrm{~b}$ \\
\hline SEM & 1.027 & 1.660 & 0.158 & 0.120 & 80.627 & 1.493 & 0.967 \\
\hline CV\% & 10.958 & 10.348 & 10.816 & 10.477 & 11.130 & 10.385 & 11.073 \\
\hline $\operatorname{LSD}(P \leq 0.05)$ & 2.86 & 4.64 & 0.44 & 0.43 & 224.06 & 4.25 & 2.7 \\
\hline \multicolumn{8}{|l|}{ ANOVA } \\
\hline \multicolumn{8}{|l|}{ District } \\
\hline$d f$ & 17 & 17 & 17 & 17 & 17 & 17 & 17 \\
\hline Sum of squares & 6,369 & 5,427 & 159.22 & 66.25 & $57,214,449$ & $1,799.0$ & 11,241 \\
\hline Mean squares & 374.6 & 319.3 & 9.366 & 3.897 & $3,365,556$ & 105.82 & 661.2 \\
\hline$F$ value & 72.7 & 23.48 & 77.06 & 54.81 & 106.6 & 9.278 & 138.1 \\
\hline $\operatorname{Pr}(>F)$ & $<2 \mathrm{e}-16^{*}$ & $<2 \mathrm{e}-16^{*}$ & $<2 \mathrm{e}-16^{*}$ & $<2 \mathrm{e}-16^{*}$ & $<2 \mathrm{e}-16^{*}$ & $3.64 \mathrm{e}-162 *$ & $<2 \mathrm{e}-16^{*}$ \\
\hline \multicolumn{8}{|l|}{ Residuals } \\
\hline$d f$ & 72 & 72 & 72 & 72 & 72 & 72 & 72 \\
\hline Sum of squares & 371 & 979 & 8.75 & 5.12 & $2,272,964$ & 821.2 & 345 \\
\hline Mean squares & 5.2 & 13.6 & 0.122 & 0.071 & 31,569 & 11.41 & 4.8 \\
\hline
\end{tabular}

${ }^{\mathrm{z}}$ Each value is the mean $\pm \mathrm{SD}$ of all observations from the different blocks of a district. Values followed by different letters within the column are significantly different at $P \leq 0.05$ according to Duncan's multiple range test. * Values are significant at $P \leq 0.05 . \mathrm{J} 2=$ second-stage juvenile, $\mathrm{Q} / \mathrm{ha}=$ quintal per hectare, $\mathrm{CV} \%=$ coefficient of variance, $\mathrm{LSD}=$ least significant difference, $\mathrm{ANOVA}=$ analysis of variance, $d f=$ degrees of freedom, and $\operatorname{Pr}=P$-value for the effect of the classification variable on the response. 
During the surveys, an overall yield loss of $20 \%$ could be attributed to the nematode infestation. The highest yield loss (44.6\%) compared with noninfested fields was recorded in Aligarh. Yield losses attributable to $M$. graminicola in upland rice have been estimated to be 16 to $32 \%$ (Haque et al. 2018) and up to $64 \%$ under severe infection (Prot et al. 1994). The nematode infestation in the nursery was considerably high in all of the districts. $M$. graminicola is one of the few plant nematodes that are equally destructive in the nursery as well as in the field (Haque et al. 2018), as also observed during this study. During the survey, villagers informed the investigators that some farmers in Aligarh, Muzaffarnagar, and Sultanpur plowed their rice fields after 4 to 5 weeks of nursery planting because of seedling growth stagnation in the nematode-infested fields, which apparently took place as a result of planting of the $M$. graminicola-infested nursery in the nematode-infested fields. Infestation in the nursery was apparently the result of the continuous raising of nursery plants in the same plot. Furthermore, close spacing of seedlings and the ideal soil conditions with adequate organic matter and moisture coupled with numerous young feeder roots available for juvenile invasion and feeding were largely responsible for the development of galls on nursery roots during a short span of 4 to 5 weeks.

This study demonstrates that the occurrence and incidence of rootknot nematodes of rice was alarmingly high in rice nurseries as well as in paddy fields in Aligarh, Lakhimpur, Muzaffarnagar, and Shahjahanpur. Farmers are generally not aware of the disease and do not use control measures to manage rice root-knot nematodes, particularly in nurseries. This has led to nematode-infested nursery stock of poor quality, which is a major source of nematode dissemination. Thus, it becomes essential to conduct regular surveys and extension work in rice growing areas to inspect rice nurseries for infestation with $M$. graminicola and advise farmers to execute appropriate management measures. Furthermore, the preparation of rice nurseries in fully or partially controlled environments, such as hydroponics, substrate culture, or in fields not having rice cultivation for at least the last 3 years, could prove to be very effective in preventing nematode infection in rice nurseries.

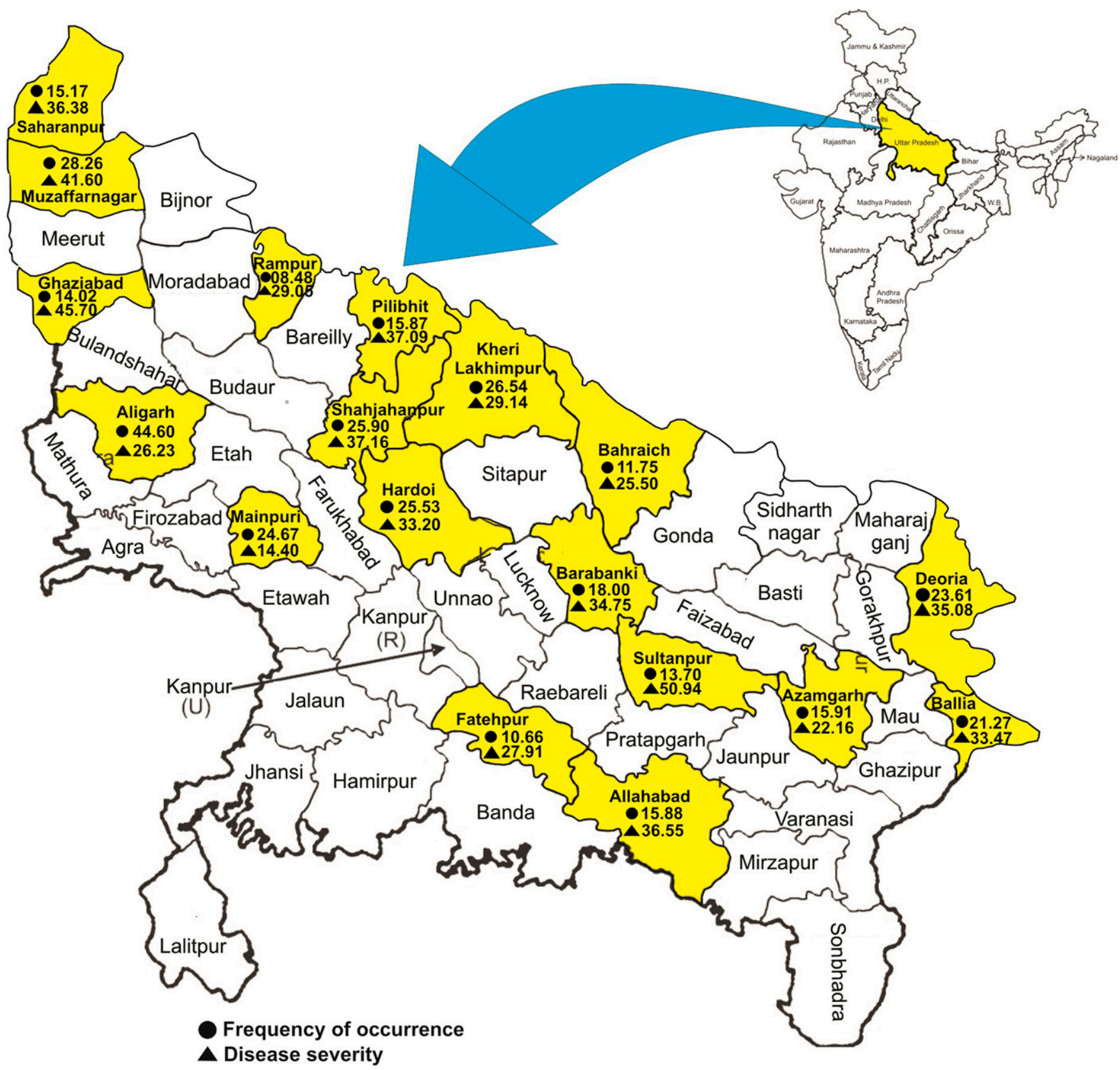

Fig. 3. District-wise distribution of frequency of occurrence and disease severity in the Aligarh, Allahabad, Azamgarh, Bahraich, Ballia, Barabanki, Sultanpur, Deoria, Fatehpur, Ghaziabad, Hardoi, Kheri Lakhimpur, Mainpuri, Muzaffarnagar, Pilibhit, Rampur, Saharanpur, and Shahjahanpur districts. 

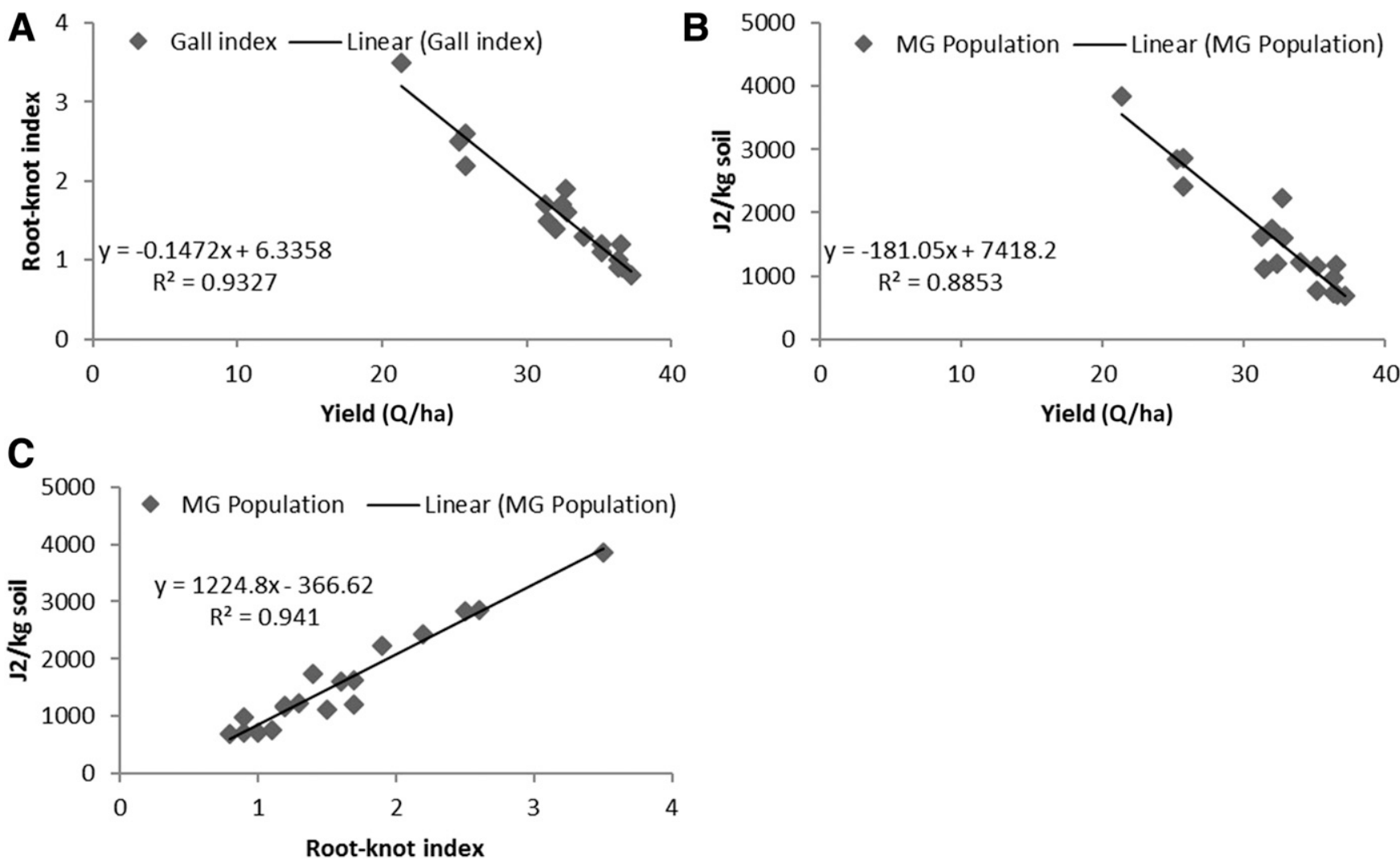

Fig. 4. Regression analysis between $\mathbf{A}$, yield and Meloidogyne graminicola (MG) soil population, $\mathbf{B}$, yield and root-knot index, and $\mathbf{C}$, soil population and root-knot index of 18 districts of Uttar Pradesh. $Q / h a=$ quintal per hectare, $Y=$ regression equation, and $R^{2}=$ coefficient of regression.

\section{Literature Cited}

Ahamad, F., and Khan, M. R. 2018. Status and yield loss assessment of rice root knot nematode, Meloidogyne graminicola infestation in Siddharthnagar District, Uttar Pradesh. Ann. Plant Prot. Sci. 26:360-364.

Babatola, J. O. 1984. Rice nematode problems in Nigeria: Their occurrence, distribution and pathogenesis. Trop. Pest Manage. 30:256-265.

Bridge, J., Luc, M., and Plowright, A. 1990. Nematodes of rice. Pages 69-108 in: Plant Parasitic Nematodes in Subtropical and Tropical Agriculture. M. Luc, R. A. Sikora, and J. Bridge, eds. CAB International, Wallingford, UK.

Bridge, J., Luc, M., Plowright, R. A., and Peng, D. 2005. Nematode parasites of rice. Pages 87-130 in: Plant parasitic nematodes in tropical and subtropical agriculture. M. Luc, R. A. Sikora, and J. Bridge, eds. Commonwealth Agricultural Bureau International, Surrey, UK.

Bridge, J., and Page, S. L. J. 1982. The rice root-knot nematode, Meloidogyne graminicola, on deep water rice (Oryza sativa subsp. indica). Rev. Nematologie 5:225-232.

Byrd, D. W., Jr., Kirkpatrick, T., and Barker, K. R. 1983. An improved technique for clearing and staining plant tissue for detection of nematodes. J. Nematol. 14: $142-143$.

Courtney, W. D., Polley, D., and Miller, V. L. 1955. TAF: An improved fixative in nematode technique. Plant Dis. Rep. 39:570-571.

Dabur, K. R., and Jain, R. K. 2005. Rice root nematode (Meloidogyne graminicola) —A threat to rice wheat cropping system. Indian J. Nematol. 34:237-238.

Dabur, K. R., Taya, A. S., and Bajaj, H. K. 2004. Life cycle of Meloidogyne graminicola on paddy and its host range studies. Indian J. Nematol. 34:80-84.

De Mendiburu, F. 2019. Statistical procedures for agricultural research. https:// tarwi.lamolina.edu.pe/ fmendiburu/

Food and Agriculture Organization of the United Nations. 2018. FAOSTAT: Food and agriculture data. http://www.fao.org/faostat/en/

Haque, Z., Khan, M. R., and Ahamad, F. 2018. Relative antagonistic potential of some rhizosphere biocontrol agents for the management of rice root-knot nematode, Meloidogyne graminicola. Biol. Control 126:109-116.

Hassan, M. G., Pant, V. R., and Devi, L. S. 2004. Infestation of rice root-knot nematode (Meloidogyne graminicola) associated with different varieties of rice in Allahabad District of Uttar Pradesh, India. Indian J. Nematol. 34:227.

Hunt, D. J., and Handoo, Z. A. 2009. Taxonomy, identification and principal species. Pages 55-97 in: Root-Knot Nematodes. R. N. Perry, M. Moens, and J. L. Starr, eds. CAB International, Wallingford, UK.

Hussey, R. S., and Barker, K. R. 1973. A comparison of methods of collecting inocula of Meloidogyne spp., including a new technique. Plant Dis. Rep. 57: 1025-1028.
Jain, R. K., Khan, M. R., and Kumar, V. 2012. Rice root-knot nematode (Meloidogyne graminicola) infestation in rice. Arch. Phytopath. Plant Prot. 45:635-645.

Jones, J. T., Haegeman, A., Danchin, E. G., Gaur, H. S., Helder, J., Jones, M. G., Kikuchi, T., Manzanilla López, R., Palomares Rius, J. E., Wesemael, W. M., and Perry, R. N. 2013. Top 10 plant parasitic nematodes in molecular plant pathology. Mol. Plant Pathol. 14:946-961.

Khan, M. R., and Anwer, M. A. 2011. Occurrence of rice root-knot nematode and yield loss assessment in Aligarh and Hathras districts of Uttar Pradesh, India. Indian J. Nematol. 41:34-40.

Khan, M. R., Haque, Z., and Kausar, N. 2014. Management of the root-knot nematode Meloidogyne graminicola infesting rice in the nursery and crop field by integrating seed priming and soil application treatments of pesticides. Crop Prot. 63:15-25

Khan, M. R., Mehboob, A., and Khan, U. 2010. Interaction of entomopathogenic nematode, Steinernema masoodi and root-knot nematode, Meloidogyne incognita on tomato. Nematol. Mediterr. 38:177-183.

Luc, M., Sikora, R. A., and Bridge, J., eds. 2005. Plant parasitic nematodes. Pages 99-105 in: Tropical and Subtropical Agriculture, 2nd ed. CAB International, Wallingford, UK.

McCouch, S. R., Wright, M. H., Tung, C. W., Maron, L. G., McNally, K. L., Fitzgerald, M., Singh, N., DeClerck, G., Agosto-Perez, F., Korniliev, P., and Greenberg, A. J. 2016. Open access resources for genome-wide association mapping in rice [published corrigendum appears in Nat. Commun. 2016;7: 11346]. Nat. Commun. 7:10532.

Plowright, R., and Bridge, J. 1990. Effect of Meloidogyne graminicola (nematode) on the establishment, growth and yield of rice cv. IR 36. Nematologica 36:81-89.

Poudyal, D. S., Pokharel, R. R., Shrestha, S. M., and Khatri-Chetria, G. B. 2005. Effect of inoculum density of rice root knot nematode on growth of rice cv. Masuli and nematode development. Australas. Plant Pathol. 34:181-185.

Prasad, J. S., Panwar, M. S., and Rao, Y. S. 1986. Chemical control of the root nematode (Hirschmaniella mucronata) in rice. Beitr. Trop. Landwirtsch. Veterinarmed. 24:65-69.

Prasad, J. S., Somasekhar, N., and Varaprasad, K. S. 2010. Nematode infestation in paddy. Pages 17-71 in: Nematode Infestations, Part I: Food Crop. M. R. Khan and M. S. Jairajpuri, eds. Indian Academy of Sciences, Bengaluru, India.

Prasad, R. 2011. Aerobic rice systems. Adv. Agron. 111:207-247.

Prot, J. C., Sorianoo, I. R. S., and Matias, D. 1994. Major root-parasitic nematodes associated with irrigated rice in the Philippines. Fundam. Appl. Nematol. 17:75-78.

Sheela, M. S., Jiji, T., Nisha, M. S., and Rajkumar, J. 2005. A new record of Meloidogyne graminicola on rice, Oryza sativa in Kerala. Indian J. Nematol. 35:218 
Singh, V. K., Kalia, C. S., and Kaul, V. 2007. New record of root-knot nematode, Meloidogyne graminicola infecting rice in Jammu. Indian J. Nematol. 37:94.

Southey, J. F. 1986. Page 446 in: Plant Nematology. Her Majesty's Stationary, London, UK.

Subbotin, S. A., Peng, D., and Moens, M. 2001. A rapid method for the identification of the soybean cyst nematode Heterodera glycines using duplex PCR. Nematology 3:365-371.
Vrain, T. C., Wakarchuk, D. A., Levesque, A. C., and Hamilton, R. I. 1992. Intraspecific rDNA restriction fragment length polymorphism the Xiphinema americanum group. Fundam. Appl. Nematol. 15:563-573.

Yik, C. P., and Birchfield, W. 1979. Host studies and reaction of cultivars to Meloidogyne graminicola. Phytopathology 69:497-499.

Zadoks, J. C. 1985. On the conceptual basis of crop loss assessment: The threshold theory. Annu. Rev. Phytopathol. 23:455-473. 